\title{
PERLINDUNGAN HUKUM BAGI KREDITUR YANG MENGGUNAKAN
} JAMINAN FIDUSIA

\author{
HIDAYAT ANDYANTO \\ Fakultas Hukum, Universitas Wiraraja Sumenep \\ h_andyanto@yahoo.co.id
}

\begin{abstract}
ABSTRAK
Keberadaan jaminan merupakan persyaratan untuk memperkecil resiko bank dalam penyaluran kredit. Dalam Undang-Undang Nomor 10 Tahun 1998 tentang Perubahan Atas Undang-Undang Nomor 7 Tahun 1992 tentang Perbankan, istilah jaminan disebut sebagai agunan. Dari undang-undang tersebut Pasal 1 Angka (23) menyebutkan bahwa, "agunan adalah jaminan tambahan yang diserahkan nasabah debitur kepada bank dalam rangka pemberian fasilitas kredit atau pembiayaan berdasarkan prinsip syariah". Mengingat bahwa jaminan sebagai salah satu unsur pemberian kredit, maka apabila berdasarkan unsur-unsur lain telah dapat diperoleh keyakinan atas kemampuan nasabah debitur mengembalikan utangnya, jaminan dapat hanya berupa barang, proyek atau hak tagih yang dibiayai dengan kredit yang bersangkutan. Sifat perjanjian jaminan merupakan perjanjian asesor (accesoir). Perjanjian jaminan merupakan "perjanjian khusus yang dibuat oleh kreditur atau bank dengan debitur atau pihak ketiga yang membuat suatu janji dengan mengikatkan benda tertentu atau kesanggupan pihak ketiga dengan tujuan memberikan keamanan dan kepastian hukum pengembalian kredit atau pelaksanaan perjanjian pokok"
\end{abstract}

Kata Kunci : Perlindungan Bagi Pengguna Jaminan Fidusia..

\section{A. PENDAHULUAN}

Bank merupakan salah satu sumber dana bagi masyarakat, salah satunya ialah dalam bentuk penyaluran kredit, baik itu penyaluran kredit bagi perorangan maupun badan usaha, sebagaimana dinyatakan dalam Pasal 1 Angka (2) Undang-Undang Nomor 10 Tahun 1998 Tentang Perubahan Atas Undang-Undang Nomor 7 Tahun 1992 Tentang Perbankan Bahwa "Bank adalah badan usaha yang menghimpun dana dari masyarakat dalam bentuk simpanan dan menyalurkannya kepada masyarakat dalam bentuk kredit atau bentuk yang lain dalam rangka meningkatkan taraf hidup rakyat banyak".
Bank telah memberikan peran penting bagi pembangunan Negara. Dengan adanya fasilitas dari lembaga perbankan berupa penyaluran kredit maka dunia usaha, industri maupun perdagangan seakan bangkit kembali. Karena pada kenyataannya dalam upaya Pembangunan ekonomi khususnya pada sektor usaha, industri dan perdagangan diperlukan tersedianya dana dalam jumlah besar. Untuk meningkatkan, memperluas dan mengembangkan usahanya, para pelaku usaha membutuhkan kucuran dana baik dalam bentuk modal maupun berupa dana pinjaman yang diberikan oleh lembaga perbankan, hal ini sesuai dengan apa yang telah dijelaskan dalam Pasal 4 Undang-Undang Nomor 7 
Tahun 1992 tentang Perbankan yang menyatakan bahwa, "Perbankan Indonesia bertujuan menunjang pelaksanaan pembangunan nasional dalam rangka meningkatkan, pemerataan, pertumbuhan ekonomi dan stabilitas nasional kearah peningkatan kesejahteraan rakyat banyak".

Berdasarkan ketentuan Pasal 8 UndangUndang Nomor 10 Tahun 1998 maka bank baru diperbolehkan menyalurkan kredit jika telah merasa yakin bahwa debitur mempunyai kemampuan dan kesanggupan dalam mengembalikan kredit. Karena semua dimaksudkan untuk menjaga stabilitas sistem keuangan dan melindungi lembaga bank serta nasabah penyimpan dana, sehingga bank diharapkan senantiasa tetap berada dalam kondisi sehat dan stabil dalam memenuhi kewajibannya kepada nasabah penyimpan dana. Hal ini sesuai dengan Pasal 29 Ayat (3) Undang-Undang Nomor 10 Tahun 1998 tentang Perubahan Atas Undang-Undang Nomor 7 Tahun 1992 tentang Perbankan juga telah menegaskan bahwa "Dalam memberikan kredit atau pembiayaan berdasarkan prinsip syariah dan melakukan usaha lainnya, bank wajib menempuh cara-cara yang tidak merugikan bank dan kepentingan nasabah yang mempercayakan dananya kepada bank".

Secara garis besar, bentuk jaminan dikenal dua macam yaitu jaminan perorangan dan jaminan kebendaan. Bentuk jaminan khusus yang paling disukai pihak bank yaitu jaminan kebendaan. Salah satu jenis jaminan kebendaan yang dikenal dalam hukum positif adalah jaminan fidusia. Sebagai lembaga jaminan atas benda bergerak, jaminan fidusia banyak digunakan oleh masyarakat bisnis karena jaminan fidusia tersebut berdasarkan pada kepercayaan (fiducia) yang mana membuka kemungkinan agar debitur tidak terhambat dalam melakukan usahanya dan masih dapat mempergunakan benda atau barang yang dijadikan sebagai obyek Jaminan fidusia tersebut.

Undang-Undang Nomor 42 Tahun 1999 tentang Jaminan Fidusia memberikan jaminan kepastian hukum dalam Pembebanan hak jaminan pada benda bergerak, dimana Status kreditur dijamin dengan adanya sistem pendaftaran Jaminan Fidusia yang berfungsi untuk mendata pembebanan benda jaminan guna mencegah terjadinya pembebanan ulang fidusia (Pasal 17 Undang-Undang Nomor 42 Tahun 1999 tentang Jaminan Fidusia). Selain itu Undang-Undang Nomor 42 Tahun 1999 tentang Jaminan Fidusia membuka peluang seluas-luasnya bagi pembebanan jaminan terhadap benda bergerak yang berwujud maupun tidak berwujud, serta benda tidak bergerak yang tidak dapat dibebani oleh hak tanggungan.

Kreditur selain memiliki hak preferensiasi (hak yang diutamakan) dalam Undang-Undang Nomor 42 Tahun 1999 tentang Jaminan Fidusia juga telah memberikan hak kepada penerima fidusia (kreditur) untuk melakukan eksekusi fidusia bila debitur wanprestasi. Sertifikat fidusia yang dikeluarkan oleh kantor pendaftaran 
fidusia telah dilengkapi dengan kalimat "Demi Keadilan Berdasarkan Ketuhanan Yang Maha Esa" yang mana memiliki kekuatan eksekutorial yang sama dengan putusan pengadilan yang telah memperoleh kekuatan hukum tetap.

Berbeda dengan gadai yang diatur dalam Pasal 1150-1160 KUHPerdata yang mengatur tentang jaminan khusus atas benda bergerak dimana obyek jaminan berada kekuasaan dalam kreditur, disini untuk jaminan fidusia obyek jaminan masih dalam kekuasaan pemilik benda (pemberi fidusia/debitur) sehingga masih dapat dipergunakan untuk kepentingan melanjutkan usaha debitur sebagai pemilik barang. Sedangkan perkreditan yang dilakukan oleh bank tidak selamanya berkualitas lancar, banyak terjadi kredit yang diberikan manjadi bermasalah yang disebabkan berbagai alasan, misalnya usaha yang biayai oleh kredit mengalami kemerosotan usaha, kalah bersaing, adanya krisis ekonomi moneter dan adanya kesengajaan debitur untuk melakukan penyimpangan dalam penggunaan kredit.

Dari segi bahasa kredit berasal dari kata bahasa latin credere, artinya kepercayaan. Dalam bahasa Belanda istilahnya Vertouwen, dalam bahasa Inggris believe atau trust or confidence artinya sama yaitu percaya. Kredit berarti kepercayaan. "Dengan demikian, sungguhpun kata "kredit" sudah berkembang kemana-mana, tetapi dalam tahap apapun dan kemanapun arah perkembangannya, dalam setiap kata "kredit" tetap mengandung unsur "kepercayaan". Apabila seseorang atau suatu badan usaha mendapat fasilitas kredit dari bank, berarti dia mendapat kepercayaan pinjaman dana dari bank.

Undang-Undang Nomor 10 Tahun 1998 tentang Perubahan Atas Undang-Undang Nomor 7 tahun 1992 tentang Perbankan di dalamnya disebutkan bahwa, "kredit adalah penyediaan uang atau tagihan yang dapat dipersamakan dengan itu, berdasarkan persetujuan atau kesepakatan pinjammeminjam antara bank dengan pihak lain yang mewajibkan pihak peminjam untuk melunasi utangnya setelah jangka waktu tertentu dengan pemberian bunga". Dalam undang-undang tersebut tidak mengenal istilah Perjanjian kredit. Istilah perjanjian kredit ditemukan dalam Instruksi Presidium kabinet nomor 15/EK/10 tanggal 3 Oktober 1966 Jo Surat Edaran Bank Negara Indonesia unit I No. 2/539/UPK/Pemb tanggal 8 Oktober 1966 yang menginstruksikan kepada masyarakat perbankan bahwa dalam memberikan kredit dalam bentuk apapun, Bank-Bank wajib mempergunakan "akad perjanjian kredit"

Menurut Mariam Darus Badrulzaman menyatakan bahwa "Perjanjian kredit bank adalah perjanjian pendahuluan dari penyerahan uang. Perjanjian pendahuluan ini merupakan hasil permufakatan antara pemberi dan penerima pinjaman mengenai hubunganhubungan hukum antara keduanya." Perjanjian ini bersifat konsensuil obligatoir sedangkan penyerahan uangnya sendiri 
bersifat riil, pada saat penyerahan dilakukan barulah berlaku ketentuan yang dituangkan dalam perjanjian kredit kedua belah pihak.

\section{B. PEMBAHASAN}

Perjanjian jaminan fidusia bukan merupakan suatu hak jaminan yang lahir karena undang-undang melainkan harus diperjanjikan terlebih dahulu antar bank dengan nasabah debitur. Menurut Pasal 4 Undang-Undang Nomor 42 Tahun 1999 Tentang Jaminan Fidusia yang menyebutkan bahwa "Jaminan fidusia merupakan perjanjian ikutan dari suatu perjanjian pokok yang kewajiban bagi para pihak untuk memenuhi suatu prestasi" dari bunyi pasal tersebut dapat dipahami bahwa pada hakikatnya sifat jaminan fidusia adalah perjanjian ikutan (accesoir), dimana perjanjian jaminan fidusia merupakan perjanjian yang lahir dan tidak terpisahkan dari perjanjian kredit bank. Hal ini berarti bahwa perjanjian jaminan fidusia tidak mungkin ada tanpa didahului oleh perjanjian lain yang disebut perjanjian pokoknya yaitu perjanjian kredit antara bank sebagai kreditur dengan debitur. Konsekuensi dari perjanjian accesoir ini adalah jika perjanjian pokok tidak sah, atau karena sebab apapun hilang berlakunya atau dinyatakan tidak berlaku, maka hukum perjanjian jaminan fidusia sebagai perjanjian accesoir juga ikut batal.

Pelaksanaan pembebanan jaminan fidusia dilakukan dengan menggunakan "Akta Jaminan fidusia", berdasarkan Pasal 5 Ayat
(1) Undang-Undang Nomor 42 Tahun 1999 Tentang Jaminan Fidusia yang menyebutkan bahwa "Pembebanan benda dengan jaminan fidusia dibuat dengan akta notaris dalam bahasa Indonesia dan merupakan akta jaminan fidusia". Dari bunyi pasal tersebut maka dapat dipahami bahwa akta jaminan fidusia haruslah dibuat secara otentik dan dibuat dalam bentuk tertulis. Menurut Pasal 1868 KUHPerdata akta otentik adalah akta yang dibuat dalam bentuk yang ditentukan oleh undang-undang yang dibuat oleh atau dihadapan pejabat yang berwenang (pegawai umum yang berkuasa) untuk itu dimana di tempat akta itu dibuat. Pegawai yang berkuasa atau pegawai umum yang dimaksud dalam Pasal 1868 KUHPerdata tersebut yaitu salah satunya adalah notaris, maka dari itu akta jaminan fidusia harus dibuat dihadapan notaris agar kekuatan pembuktian dianggap sah dan benar tanpa perlu membuktikan atau menyelidiki keabsahan tanda tangan pihak tersebut.

Akta jaminan fidusia merupakan hal yang penting dalam perjanjian jaminan fidusia, karena keterkaitan sifat perjanjian jaminan fidusia dengan perjanjian kredit dapat dilihat dari isi akta jaminan fidusia.

Jaminan fidusia dapat diberikan kepada lebih dari satu penerima fidusia atau kepada kuasa atau wakil dari penerima fidusia tersebut (Pasal 8 Undang-Undang Nomor 42 Tahun 1999 Tentang Jaminan Fidusia). Pemberian jaminan fidusia kepada lebih dari satu penerima fidusia bukan berarti jaminan fidusia tersebut diberikan pada lebih dari satu 
kreditur terhadap beberapa perjanjian kredit, tetapi hanya dapat dilakukan dalam hal-hal yang khusus saja misalnya dalam hal pemberian kredit sindikasi. Kredit sindikasi adalah persetujuan antara dua bank atau lebih untuk memberikan fasilitas kredit kepada satu atau beberapa orang dengan menggunakan satu bentuk perjanjian kredit. Sedangkan yang dimaksud wakil penerima fidusia yaitu orang yang secara hukum dianggap mewakili penerima fidusia dalam penerimaan jaminan fidusia.

Hal lain yang tidak kalah penting untuk diketahui dalam hal pembebanan jaminan fidusia adalah obyek jaminan fidusia. Yang dimaksud obyek jaminan fidusia adalah benda-benda apa yang dapat dijadikan jaminan utang dengan dibebani jaminan fidusia. Berdasarkan pengertiannya menurut Pasal 1 Angka (2) dan (4) Undang-Undang Nomor 42 Tahun 1999 Tentang Jaminan fidusia, yang dapat dijadikan obyek jaminan fidusia adalah benda apapun yang dapat dimiliki, dan hak kepemilikannya dapat dialihkan. Benda-benda tersebut dapat berupa benda berwujud maupun tidak berwujud, terdaftar maupun tidak terdaftar, bergerak maupun tidak bergerak. Untuk benda tidak bergerak dengan berdasarkan pada Pasal 3 Undang-Undang Nomor 42 Tahun 1999 Tentang Jaminan Fidusia dikenai persyaratan sebagai berikut:

1. Benda-benda tersebut tidak dapat dibebani dengan hak tanggungan, hak tanggungan yang berkaitan dengan tanah dan bangunan, sepanjang peraturan yang berlaku menentukan jaminan tersebut harus didaftar;

2. Benda-benda tersebut tidak dapat dibebani hipotek. Sebagaimana dimaksud dalam Pasal 1162 jo Pasal 314 Ayat (3) KUH Dagang atau hipotik atas kapal laut sebagaimana diatur dalam Pasal 49 Undang-Undang Nomor 21 Tahun 1992 Tentang Pelayaran yang menyatakan bahwa kapal yang telah didaftar dapat dibebani dengan hipotik;

3. Benda-benda tersebut tidak dapat dibenani hipotik atas pesawat terbang sebagaimana dimaksud dalam Pasal 12 Undang-Undang Nomor 15 Tahun 1992 Tentang Penerbangan.

Selanjutnya Pasal 9 Undang-Undang Nomor 42 tahun 1999 Tentang Jaminan Fidusia menyatakan bahwa Jaminan fidusia dapat diberikan terhadap satu atau lebih satuan benda, termasuk piutang, baik yang telah ada pada saat jaminan diberikan mapun yang diperoleh kemudian. Sedangkan tentang benda yang diperoleh kemudian ini berarti bahwa benda tersebut akan dibebani jaminan fidusia pada saat benda dimaksud menjadi milik pemberi fidusia.

Pasal 10 Undang-Undang Nomor 42 Tahun 1999 Tentang Jaminan Fidusia bahwa jaminan fidusia meliputi hasil dari benda yang menjadi obyek jaminan fidusia, serta meliputi klaim asuransi dalam hal benda yang menjadi obyek jaminan diasuransikan. Klaim asuransi akan menggantikan benda yang menjadi 
obyek jaminan jika terjadi resiko yang menyebabkan obyek jaminan musnah.

Pembebanan jaminan fidusia dalam pelaksanaan perjanjian kredit merupakan proses penandatanganan perjanjian kredit dan atau perjanjian jaminan oleh debitur sebelum diberikan fasilitas pinjaman, sebagai bukti adanya perikatan antara pihak bank dan pihak debitur. Apabila dalam perjanjian kredit tersebut pihak debitur wanprestasi maka pihak bank mempunyai cukup bukti untuk melaksanakan haknya yang timbul berdasarkan perjanjian kredit dengan jaminan fidusia tersebut. Hal tersebut untuk menjaga keamanan atau kepentingan bank dari segi hukum atas pemberian fasilitas kredit yang diberikan kepada debitur.

Langkah selanjutnya setelah akta jaminan fidusia dibuat yaitu dilakukan pendaftaran Akta Jaminan Fidusia sebagaimana dijelaskan pada Pasal 11 Ayat (1) Undang-Undang Nomor 42 Tahun 1999 Tentang Jaminan Fidusia yang menyatakan bahwa "Benda yang dibebani dengan jaminan fidusia wajib didaftarkan". Dari ketentuan pasal tersebut dapat dipahami bahwa pendaftaran jaminan fidusia sangatlah penting untuk memperoleh kepastian hukum bagi para pihak yang berkepentingan, selain melahirkan hak kebendaan juga untuk memenuhi unsur publisitas maksudnya semakin terpublikasi jaminan utang akan semakin baik, sehingga kreditur dan khalayak ramai dapat mengetahui. Dengan dilaksanakannya pendaftaran benda yang dijamin dengan fidusia dikantor pendaftaran fidusia, maka masyarakat dapat mengetahui bahwa suatu benda telah dibebani jaminan fidusia sehingga masyarakat akan berhati-hati untuk melakukan transaksi atas benda tersebut dari obyek jaminan fidusia dan sekaligus dapat memberikan kepastian hukum bagi kreditur lainnya mengenai benda yang telah dibebani jaminan fidusia. Selain itu dengan dilakukannya pendaftaran pada kantor pendaftaran jaminan fidusia dapat memberikan hak yang didahulukan (preference) kepada penerima fidusia terhadap kredit yang lain.Hal Ini disebabkan jaminan fidusia memberikan hak kepada pemberi fidusia untuk tetap menguasai bendanya yang menjadi obyek jaminan fidusia berdasarkan kepercayaan.

Masalah pendaftaran jaminan fidusia memiliki arti yuridis sebagai suatu rangkaian yang tidak terpisah dari proses terjadinya perjanjian jaminan fidusia. Walaupun pendaftaran jaminan fidusia sedemikian penting, dalam praktik perkreditan dilingkungan bank masih ada perjanjian jaminan fidusia yang tidak didaftarkan. Akibat hukum dari perjanjian jaminan fidusia yang tidak didaftarkan adalah "tidak melahirkan perjanjian kebendaan bagi jaminan fidusia tersebut, sehingga karakter kebendaan seperti doit de suite (mengikuti benda dalam tangan siapapun) dan hak preferensi tidak melekat pada kreditur pemberi jaminan fidusia”.

Pendaftaran jaminan fidusia dilakukan pada kantor pendaftaran fidusia yang berada 
dalam lingkup Departemen Hukum dan Hak Asasi Manusia sebagaimana yang disebutkan dalam Pasal 12 Undang-Undang Nomor 42 Tahun 1999 Tentang Jaminan Fidusia. Dalam hal benda yang dibebani dengan jaminan fidusia berada diluar wilayah Negara Republik Indonesia maka tetap harus didaftarkan dikantor pendaftaran fidusia ditempat kedudukan pemberi fidusia.

Permohonan pendaftaran jaminan fidusia dilakukan oleh penerima fidusia, kuasa atau wakilnya dengan melampirkan pernyataan pendaftaran jaminan fidusia (Pasal 13 Ayat (1) Undang-Undang Nomor 42 Tahun 1999 Tentang Jaminan Fidusia). Dalam prakteknya kreditur memberikan kuasa kepada notaris yang membuat akta jaminan fidusia untuk melakukan pendaftaran akta jaminan fidusia di kantor pendaftaran fidusia. Dalam Pasal 13 Ayat (2) Undang-Undang Tentang Jaminan Fidusia.

Sertifikat jaminan fidusia yang telah diterbitkan oleh kantor pendaftaran jaminan fidusia tersebut, kemudian diserahkan kepada kreditur sebagai penerima fidusia. Dalam sertifikat jaminan fidusia telah dicantumkan kata-kata "DEMI

KEADILAN BERDASARKAN KETUHANAN YANG MAHA ESA" (Pasal 15 Ayat (1) UndangUndang Nomor 42 Tahun 1999 Tentang Jaminan Fidusia), sertifikat jaminan fidusia tersebut mempunyai kekuatan eksekutorial yang sama dengan putusan pengadilan yang mempunyai kekutan hukum yang tetap (Pasal 15 Ayat (2) Undang-Undang Nomor 42 Tahun
1999 Tentang Jaminan Fiduisia). Kekuatan eksekutorial berarti berdasarkan sertifikat jaminan fidusia tersebut, kreditur dapat langsung melaksanakan eksekusi atau penjualan jaminan fidusia tanpa melalui pengadilan dan bersifat final serta mengikat para pihak untuk melaksanakan penjualan tersebut. Dengan demikian berdasarkan Pasal 15 Ayat (3) Undang-Undang Nomor 42 Tahun 1999 Tentang Jaminan Fidusia maka apabila debitur cidera janji, maka penerima fidusia mempunyai hak menjual benda yang menjadi obyek jaminan fidusia atas kekuasaannya sendiri.

Apabila terjadi perubahan mengenai halhal yang tercantum dalam sertifikat jaminan fidusia, maka penerima fidusia wajib mengajukan permohonan pendaftaran atas perubahan tersebut kepada kantor pendaftaran fidusia. Seperti telah diuraikan bahwa sertifikat jaminan fidusia harus memuat keterangan atau pernyataan serta identitas pihak pemberi dan penerima fidusia, tanggal, nomor akta jaminan, nama dan kedudukan notaris yang memuat akta jaminan fidusia, data perjanjian pokok yang dijamin fidusia, uraian mengenai benda yang menjadi obyek jaminan fidusia, nilai penjaminan dan nilai benda yang menjadi obyek jaminan fidusia. Pada perkembangannya bisa saja data-data tersebut berubah misalnya jumlah utang pokok berubah, jangka waktu perjanjian kredit berubah, nilai benda yang menjadi obyek jaminan berubah, maka kreditur wajib mengajukan permohonan pendaftaran atas 
perubahan tersebut kepada kantor pendaftaran fidusia. Kemudian kantor pendaftaran fidusia pada tanggal yang sama dengan tanggal penerimaan permohonan perubahan, melakukan pencatatan perubahan tersebut dalam buku daftar fidusia dan menerbitkan pernyataan perubahan yang merupakan bagian tak terpisahkan dari sertifikat jaminan fidusia.

\section{PENUTUP}

Pembebanan jaminan fidusia dalam perjanjian kredit dilakukan dengan pembuatan akta jaminan fidusia oleh notaris, kemudian didaftarkan pada kantor pendaftaran jaminan fidusia, kreditur wajib melampirkan pernyataan pendaftaran jaminan fidusia. Jika telah dilakukan pendaftaran maka kantor pendaftaran jaminan fidusia menerbitkan sertifikat jaminan fidusia yang dilengkapi dengan kata-kata "DEMI KEADILAN BERDASARKAN KETUHANAN YANG MAHA ESA" mempunyai kekuatan eksekutorial bagi kreditur terhadap obyek jaminan jika terjadi kredit macet.

Pemberian kredit dengan jaminan fidusia besar kemungkinan terjadi resiko obyek jaminan musnah yang menyebabkan hapusnya jaminan fidusia. Apabila obyek jaminan fidusia tersebut diasuransikan maka klaim asuransi akan dapat menjadi pengganti obyek jaminan yang musnah tersebut. Apabila obyek jaminan tidak diasuransikan maka kreditur tunduk pada Pasal 1131 KUHPerdata tentang jaminan umum. Penyelesaian jika terjadi kredit macet bagi Bank milik pemerintah melalui Panitia Urusan Piutang Negara (PUPN) sedangkan Bank milik swasta melalui Pengadilan Negeri.

\section{DAFTAR PUSTAKA}

Frieda Husni Hasbullah, 2002, Hukum Kebendaan Perdata Jilid 2, Ind Hill Co, Jakarta Selatan.

Johannes Ibrahim, 2004, Croos Default and cross Collateral Sebagai Upaya Penyelesaian Kredit Bermasalah, Refika Aditama, Bandung.

Peter Mahmud Marzuki, 2005, Penelitian Hukum, Kencana, Surabaya.

Salim HS, 2004, Perkembangan Hukum Jaminan di Indonesia, Raja Grafindo Persada, Jakarta.

Tan Kamelo, 2004, Hukum Jaminan Fidusia Suatu Kebutuhan yang Didambakan, Alumni, Bandung.

Kitab Undang-Undang Hukum Perdata (KUHPerdata).

Undang-Undang Nomor Nomor 10 Tahun 1998 tentang Perubahan Atas Undang-Undang Nomor 7 Tahun 1992 tentang Perbankan.

Undang-Undang Nomor 42 Tahun 1999 tentang Jaminan Fidusia.

Peraturan Pemerintah Republik Indonesia Nomor 86 Tahun 2000 tentang Tata Cara Pendaftaran Jaminan Fidusia dan Biaya Pembuatan Akta Jaminan Fidusia. 